Palaeoclimatology

\title{
Onset of the ice age in the North Atlantic
}

\section{from Brian Funnell}

IN a paper published in this issue of Nature (see page 620), Shackleton and colleagues ${ }^{1}$ complete a careful interdisciplinary study of sediment cores obtained in the northeast Atlantic and establish with admirable precision that ice-rafted debris first appeared there about 2.5 Myr BP, with the first major input of debris slightly later, at 2.37 Myr BP. The results make it possible to assert with confidence that the North Atlantic and its bordering continents have been subject to periodic glaciation for no less than the past two and a half million years.

Although earlier investigations ${ }^{2}$ of deepsea sediments had indicated ice-rafting of debris into the North Atlantic from as long ago as approximately $3 \mathrm{Myr}$, it was not until the hydraulic piston corer was added to the Deep Sea Drilling Project's range of equipment that good-quality cores, suitable for detailed analysis, could be extracted from deep enough into ocean sediments to allow a full interpretation of the time period earlier than half a million years ago.

Shackleton and colleagues investigated one of the earlier cores to be obtained with the hydraulic piston corer (Leg 81, site 552A of the Deep Sea Drilling Project, from a depth of 2,300 metres) using a combination of micropalaeontological, palaeomagnetic and stable oxygen isotope methods.

The magnitude of the oxygen isotope signal (which mainly reflects global ice volumes) and the abundance of ice-rafted debris at 2.37 Myr leave no doubt that the extent of this episode of glaciation in and around the North Atlantic is fully comparable with the most recent glacial episode, which culminated only 18,000 years ago and melted back between 11,000 and 6,000 years ago.

This new date for the onset of general Northern Hemisphere glaciation accords well with a date of $2.4 \mathrm{Myr}$ proposed by workers in the Netherlands ${ }^{3}$ for the first indication of major cooling in and around the southern margins of the North Sea. Here there is unequivocal evidence of a massive conversion of a temperate forest cover into cold heath conditions, although there is so far no evidence of actual glacierization.

The carbonate content of the deep-sea sediments ${ }^{1}$ (which varies in inverse proportion to the ice-rafted component) shows that before 2.5 Myr BP there was no significant sea ice in the North Atlantic. The stable oxygen isotope record shows that before $2.37 \mathrm{Myr}$ ice volume maxima were absolutely less extreme, although subdued fluctuations, presumably mainly due to variations in the volume of the earlier and older Antarctic polar ice cap, still continue into the more remote past.

From the carbon isotope record of the core sediments it is clear that the formation of North Atlantic deep water by winter cooling at the surface of the NorwegianGreenland Sea was already established by 3.5 Myr ago, before the onset of glaciation. The surface water, being cold and dense, sinks to the bottom of the North Atlantic. There it gives rise to a higher ${ }^{13} \mathrm{C}$ content in bottom- living calcareous microfossils than do the 'older' Antarctic bottom waters which have had more time to gain ${ }^{12} \mathrm{C}$ from the oxidation of ${ }^{12} \mathrm{C}$-rich organic matter falling through the water column.

Since site 552A was drilled, Leg 94 of the Deep Sea Drilling Project has explored six more sites in the North Atlantic using the hydraulic piston corer ${ }^{4}$, with the specific intention of elucidating the history of North Atlantic waters over the last few million years. What we can look forward to now is a detailed spatial and temporal record of past climatic changes in this critical North Atlantic area which will be invaluable for a better understanding of the mechanisms that control its physical oceanography and surrounding climate. $\square$

Brian Funnell is Professor in the School of Environmental Sciences at the University of East Anglia, Norwich NR4 $7 J J$.

Shackleton, N.J. et al. Nature 307, 620 (1984).

Berggnen, W A Init, Rep. DSDP 12, 953 (1972).

3. Suc, J-P. \& Zagwijn, W.H. Boreas 12, (1983).

4. Kidd, R.B. et al. Nature 30, 532 (1983)

\section{Neurobiology}

\section{Building acetylcholine receptors}

\section{from Charles $F$. Stevens}

THE Kyoto group has done it again. Just three months ago, Nature's report on the C Cold Spring Harbor Symposium on molecular neurobiology noted that an important advance in channel research could be achieved by the expression in cultured cells of cDNA coding for the four kinds of acetylcholine receptor (AChR) subunits (see News and Views 306, 14; 1983). Numa and his colleagues at Kyoto University have now taken this prize and at the same time made an unexpected observation on the relation between receptor structure and function (see this issue of Nature, p.604).

Recall that channels are integral membrane proteins responsible for the electrical activity of the nervous system and that the AChR is the best studied such molecule. The AChR is a pentameric membrane protein composed of four subunits assembled with the stoichiometry $\alpha_{2} \beta \delta \gamma$. Binding of acetylcholine to the receptor opens the door of a water-filled cation-selective pore for about a millisecond and lets half a million ions traverse the membrane. The channel protein has been purified, partially sequenced, functionally reconstituted, the cDNA for all four subunits has been cloned and sequenced, and genomic clones for at least one of the subunits have been identified and partly-sequenced. The function of single copies of the AChR has been studied with the single-channel recording method.

As the report of the molecular neurobiology symposium pointed out, one of the next steps in clarifying the relationship between molecular structure and function would be to get the cDNA expressed in an appropriate system. Once expression has been achieved, protein structure can be altered rationally and systematically by modifying the DNA, providing a powerful tool for discovering what part subunits, domains and specific amino acids play in the operation of the AChR. The Kyoto group has made a significant start on this programme and has used an interesting approach.

There are three steps to success: cons structing an expression vector, finding a method for making appropriate quantities of AChR mRNA and using a system that synthesizes and assembles receptors, and inserts them into surface membrane. Numa and co-workers combined three approaches that previously had been successful in different contexts.

O'Hare et al. (Proc. natn. Acad. Sci. U.S.A. 78, 1527; 1981) constructed an expression vector that can be used to transfect cultured cells so that they will express a foreign protein. The Kyoto group used a version of this vector to transfect a cell line, designated COS, prepared by Gluzman (Cell 23, 175; 1981) that contains as part of its genome the simian virus $\mathbf{4 0}$ (SV40) DNA required for replication of that virus. The vector used by the Kyoto group contains the replication origin of the SV40 DNA and is thus easily replicated by COS cells: the result is that DNA coding for the AChR subunits is amplified and a relatively large amount of mRNA is made. Cultures were separately transfected with cDNA for each of the four types of AChR subunit, and mRNA coding for each subunit was isolated from the transfected cell lines. This message was then combined and injected into frog oocytes for transla- 